\title{
Limited movement in blue rockfish Sebastes mystinus: internal structure of home range
}

\author{
Salvador J. Jorgensen ${ }^{1,3, *}$, David M. Kaplan ${ }^{1}$, A. Peter Klimley ${ }^{1}$, Steven G. Morgan ${ }^{2}$, \\ Michael R. O'Farrell ${ }^{1}$, Louis W. Botsford ${ }^{1}$ \\ ${ }^{1}$ Department of Wildlife, Fish and Conservation Biology, University of California, Davis, California 95616, USA \\ ${ }^{2}$ Bodega Marine Laboratory, PO Box 247, Bodega Bay, California 94923, USA
}

${ }^{3}$ Present address: Tuna Research and Conservation Center, Hopkins Marine Station of Stanford University and Monterey Bay Aquarium, 120 Oceanview Boulevard, Pacific Grove, Callifornia 93950, USA

\begin{abstract}
Home range has been estimated for a limited number of marine fishes; however, the use of space and timing of activities within the home range has rarely been studied. In addition, understanding movement patterns of exploited fish species has been identified as a crucial science gap, impeding informed marine reserve design. We used a radio-acoustic positioning telemetry (VRAP) system to monitor detailed movements of 10 blue rockfish Sebastes mystinus around shallow rock pinnacles and stands of bull kelp Nereocystis leutkeana in central California in September 2002. The mean home range was $8783 \mathrm{~m}^{2} \pm 1137 \mathrm{SE}$; however, activity was highly concentrated in 1 to 3 core areas within each home range. Mean core areas measured $1350 \mathrm{~m}^{2} \pm 286 \mathrm{SE}$, but accounted for $\sim 83 \%$ of activity. All core areas were centered over rock pinnacles where rockfish were highly aggregated. Individuals exhibited high site fidelity and made only brief radial excursions away from these centers or moved directly from one pinnacle to the next along defined corridors. Patterns of diel activity and nocturnal sheltering corresponded closely with nautical twilight. Cores overlapped, but estimated locations of nocturnal shelters differed significantly among individuals. Movement patterns were correlated with wind velocity, upwelling index, water temperature and habitat structure.
\end{abstract}

KEY WORDS: Sebastes mystinus $\cdot$ Rockfish $\cdot$ Movement $\cdot$ Home range $\cdot$ Tagging $\cdot$ Core areas Resale or republication not permitted without written consent of the publisher

\section{INTRODUCTION}

The interaction between environmental heterogeneity and individual animal movement has important implications for metapopulation biology (Hanski 1998), home-range dynamics (Kenward et al. 2001) and spatial management (Woodroffe \& Ginsberg 1998). Individual movement ultimately plays a critical role in determining local population density, genetic structure (King \& Lawson 1995) and community composition (Ellner \& Fussmann 2003), and in rescuing populations from extinction (Hill et al. 2002). In this study, we examined how habitat structure and environmental variability influence the fine-scale movement patterns of the blue rockfish Sebastes mystinus.

Fish movement patterns are particularly relevant to marine management and conservation (Sale et al. 2005). The extent of home ranges relative to marine reserve size is likely to be of primary importance in determining the function of reserves for population persistence in terrestrial (Woodroffe \& Ginsberg 1998) and marine (Kramer \& Chapman 1999) environments due to edge effects. The percentage of the home range that extends beyond a reserve boundary is proportional to the probability of an individual being fished. The creation of new marine reserves to protect fished species has been proposed in numerous locations worldwide (Sale et al. 2005), but the home range and spatial utilization patterns of most fished species remains unknown, especially in temperate regions (Lowe et al. 2003).

Among the few studies examining movement within home ranges, disproportionately high use of particular areas within the home range (core areas) has commonly been detected (e.g. Holland et al. 1993, 1996, Meyer et al. 2000, Eristhee \& Oxenford 2001, Lowe et al. 2003, Parsons et al. 2003). The use of core areas 
among terrestrial animals has been attributed to patterns of refuging (e.g. Hamilton \& Watt 1970) and foraging (Samuel et al. 1985, Kenward et al. 2001). Patterns of core area use in marine fishes are also likely to have important implications for understanding the ecological determinants of space use; however, very little is known other than that core areas are increasingly detected as tracking technologies improve. Holland et al. (1993) identified core areas within which juvenile hammerhead sharks Sphyrna lewini restricted their diurnal movements to a small portion of their total home range (a turbid portion of an island bay), suggesting an anti-predation function. In the oceanic environment, adult $S$. lewini aggregate at oceanic seamounts during the day, and from these refuging cores make nocturnal foraging movements into a much broader pelagic environment (Klimley \& Nelson 1984). Parsons et al. (2003) identified core areas for 4 individual snapper Pargus auratus that were relatively stable over a period of 4 lunar cycles, while a fifth individual gradually changed the number and location of occupied cores. The location and timing of core area use was not, however, attributed to particular activities or habitat resources. While the quality of habitat is likely to influence the extent (Mathews 1990, Lowe et al. 2003) and the shape (e.g. Holland et al. 1996, Topping et al. 2005) of the home range, the extent to which it influences the density structure of space usage inside the home range remains relatively unknown.

Sebastes mystinus is primarily a planktivore, consuming zooplankters including thaliaceans, ctenophores and pelagic hydrozoans (Hallacher \& Roberts 1985, Hobson \& Chess 1988). It ranges in the eastern Pacific from southern Alaska to northern Mexico, and in California makes up a major fraction of the recreational fish catch (Love et al. 2002). Most females become sexually mature by $5 \mathrm{yr}$, and spawn between January and March (Miller \& Geibel 1973).

Upwelling/relaxation dynamics are thought to control the nearshore density of planktonic food resources on which blue rockfish depend (Hobson \& Chess 1988, Hobson et al. 1996), and these rockfish are most abundant in northern California (Miller \& Geibel 1973, Love et al. 2002) where coastal upwelling/relaxation cycles are strong (Send et al. 1987, Strub et al. 1987). In this region, spring and summer wind conditions are predominantly upwelling favorable. Superimposed on the annual upwelling cycle are fluctuations in wind strength on time scales ranging from $1 \mathrm{~d}$ to 1 mo that occur during all seasons. These fluctuations are large near latitude $39^{\circ} \mathrm{N}$ and produce regular peaks and relaxations in wind strength (Send et al. 1987). Relaxation periods, characterized by current reversal and shoreward transport, have been associated with higher plankton densities and increased invertebrate larvae settlement along the northern California coastline (eg. Wing et al. 1995a). During these reversals, rapid local environmental changes in temperature and plankton densities occur (Hobson \& Chess 1988), and there is an immediate feeding response by blue rockfish to increased zooplankton densities (Hobson et al. 1996).

The objective of the present study was to quantify the size and internal structure of the home range of Sebastes mystinus, and determine patterns of spatial aggregation, site fidelity and habitat association. We used a radio-acoustic positioning system (for description see Klimley et al. 2001) to monitor detailed movement and identify core areas of higher use within the home range. We examined how movement patterns covaried with environmental variability and suggest mechanisms that could explain the observed size, location and internal usage of the home range.

\section{MATERIALS AND METHODS}

Study site. This study was conducted at Fort Ross State Park $\left(38^{\circ} 30^{\prime} \mathrm{N}, 123^{\circ} 14^{\prime} \mathrm{W}\right)$ in Northern California (Fig. 1) during September of 2002, a period characterized by the transition from monthly, mean, equatorward summer winds to monthly mean, poleward winds. The nearshore habitat in this region is comprised of high relief rocky substrate interspersed with small sand and boulder beaches. Dense stands of the bull kelp Nereocystis leutkeana typically cover the rocky bottom from the high surf line to $14 \mathrm{~m}$ depth.

Tagging and telemetry tracking. We tagged 10 blue rockfish averaging $356 \mathrm{~mm}$ total length with continuous pulsing, ultrasonic, acoustic transmitters (Vemco Model V-16, $16 \times 58 \mathrm{~mm}$ ). Rockfish were captured in shallow water $(<5 \mathrm{~m})$ using barbless hooks and, upon capture, were placed in a $100 \times 50 \mathrm{~cm}$ cooler with a solution of seawater and $10 \%$ methylethyl sulfate (MS 222, $0.15 \mathrm{~g} \mathrm{l}^{-1}$ ) for anesthetization. An individual was considered adequately sedated after approximately $5 \mathrm{~min}$ when it lost equilibrium (Level 4 sedation) and rolled over completely onto its flank. Once anesthetized, the rockfish were placed on a padded tagging board for measurement and surgery. We made a $2 \mathrm{~cm}$ incision $1 \mathrm{~cm}$ to the right of the ventral midline between the pelvic fins and the anus, and then implanted the acoustic beacon in the peritoneal cavity. The incision was then closed using surgical staples (Davis \& Geck, Appose 35R). Fish were handled with latex gloves coated with a solution of antiseptic (Stress Coat) to avoid damage to the slime coat and prevent bacterial infection. After surgery, we placed individuals in a second cooler containing fresh seawater for a brief period of recovery and observation. Once fish had regained equilib- 


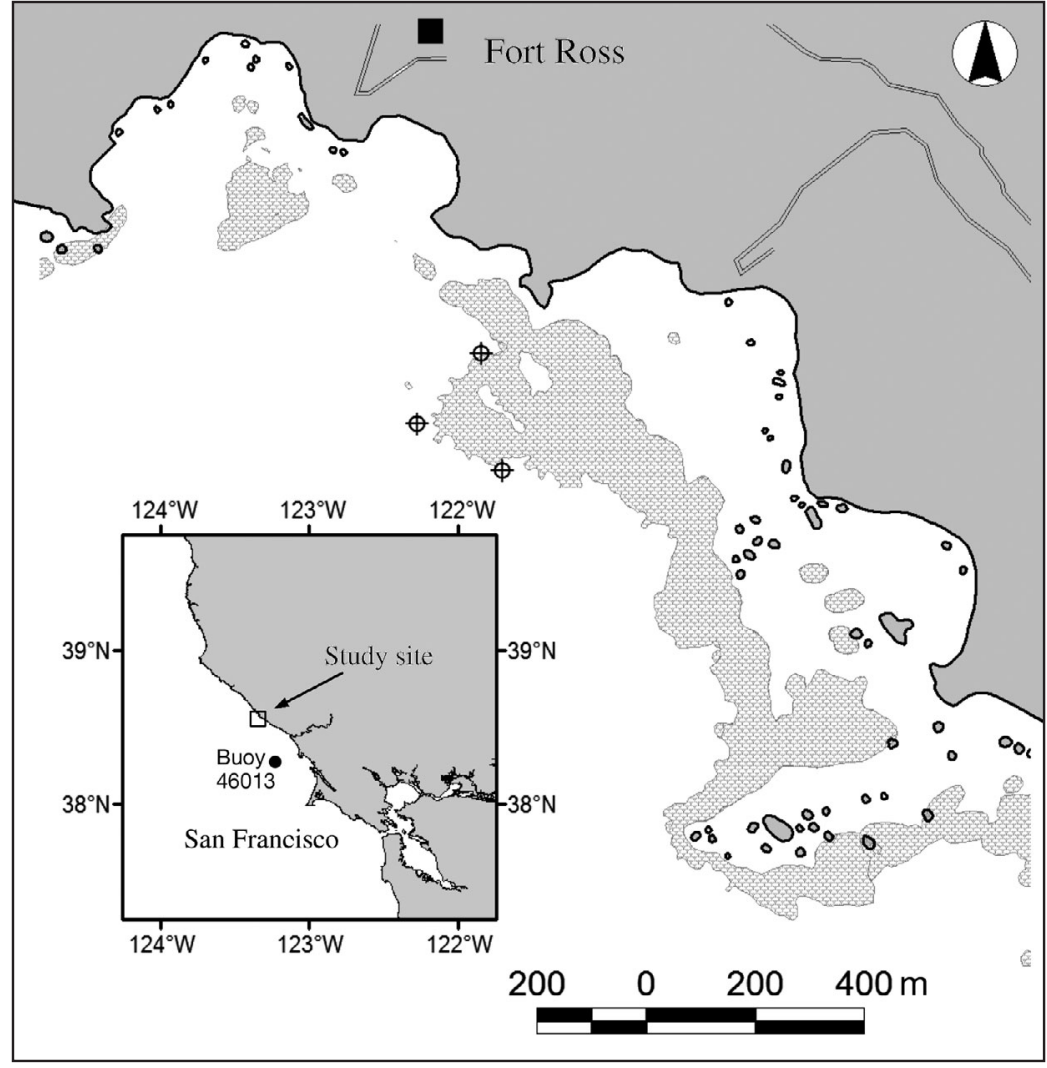

Fig. 1. Sebastes mystinus. Location of study area along coast of northern California. Shading: Nereocystis leutkeana kelp beds; $(\oplus)$ VRAP moorings

through physical barriers such as large rocks, therefore no position can be recorded for a fish when situated in a rock crevice. If the time between consecutive positions exceeded $30 \mathrm{~min}$ (10 detection cycles) we assumed that the individual had taken refuge in a rocky crevice. This assumption seems reasonable since there was no evidence that individuals were leaving the detection range of the VRAP system (e.g. a 'trail' of positions leading outward), and since blue rockfish are known to shelter in crevices, particularly at night (Love et al. 2002).

Environmental measurements. Water temperature at the study site was recorded every 6 min using a temperature logger (Onset Computers, Hobo Tidbit) moored at $7 \mathrm{~m}$ depth. The Pacific Fisheries Environmental Laboratory (PFEL) upwelling index was used as a regional measure of upwelling intensity. The PFEL generates indices of the intensity of large-scale, wind-induced coastal upwelling based on estimates of offshore Ekman transport determined from sea surface pressure fields, which are provided by the US Navy Fleet Numerical Meteorological and Oceanographic Center, Mon-

rium we released them at the location of initial capture after a period of ca. $10 \mathrm{~min}$. For analysis, data were collected only after all fish were tagged, 1 to $4 \mathrm{~d}$ after tagging (mean $=2.2 \mathrm{~d}$ ). The sex of individuals was not determined since the study did not take place during the spawning period.

For telemetry tracking we placed 3 sonobuoys (Vemco, VRAP) in a triangular configuration surrounding a kelp stand, in which all the rockfish were tagged (Fig. 1). This enabled us to simultaneously monitor movements of the 10 individuals over a period of 24 consecutive days (Table 1). We used VRAP software for determining individual positions averaged from several rapid detections. The VRAP system records tag positions with an accuracy of $\pm 2 \mathrm{~m}$ (see Figs. $4 \& 5$ in Klimley et al. 2001) at a sampling frequency equal to the time required for the system to cycle through all tags $(20 \mathrm{~s}$ $\operatorname{tag}^{-1}$ ) and record the position of each of the 10 tags (ca. $200 \mathrm{~s}$ ).

The VRAP buoys were deployed continuously between September 3 and 27 with only brief interruptions. On 11 occasions the system was not monitoring for an average period of $90 \mathrm{~min}$ each. The ultrasonic signal from the acoustic tags does not propagate terey, California (www.pfeg.noaa.gov/products/PFEL). Values for the region of this study $\left(125^{\circ} \mathrm{W}, 39^{\circ} \mathrm{N}\right)$ were downloaded from the website and are expressed as $\mathrm{m}^{3}$ $\mathrm{s}^{-1} 100 \mathrm{~m}^{-1}$ coastline. Hourly wind velocity and sea surface temperature data were acquired from National Data Buoy Center (NDBC) Buoy 46013, deployed at

Table 1. Sebastes mystinus. Size and identification of 10 ind., tagged and tracked for up to $25 \mathrm{~d}$ in September 2002

\begin{tabular}{|lccc|}
\hline Fish no. & $\begin{array}{c}\text { Total length } \\
(\mathrm{cm})\end{array}$ & Date tagged & $\begin{array}{c}\text { Tracking duration } \\
\text { (d) }\end{array}$ \\
\hline R1 & 34 & Sep 6 & 21 \\
R2 & 36 & Sep 4 & 23 \\
R3 & 35 & Sep 7 & 20 \\
R4 & 34 & Sep 7 & 20 \\
R5 & 36 & Sep 3 & 24 \\
R6 & 35 & Sep 6 & 21 \\
R7 & 35 & Sep 3 & 24 \\
R8 & 35 & Sep 4 & 23 \\
R9 & 36 & Sep 3 & 24 \\
R10 & 40 & Sep 6 & 6 \\
Mean \pm SE & $35.6 \pm 0.5$ & & 20.6 \\
\hline
\end{tabular}


$38^{\circ} 13^{\prime} \mathrm{N}, 123^{\circ} 20^{\prime} \mathrm{W}, 25 \mathrm{~km}$ west of Bodega Bay (Fig. 1; see also: http://ndbc.noaa.gov/). Wind stress was calculated from wind velocity after correction to standard measurement height $(10 \mathrm{~m})$ using the coefficient of drag in Large \& Pond (1981). The principal axis of wind variability was determined $\left(315^{\circ}\right.$ clockwise from north), and the wind stress along this direction was averaged to produce daily mean values. Sunrise, sunset and moon phase data was obtained from the Astronomical Applications Department of the US Naval observatory, published for Fort Bragg $\left(123^{\circ} 48^{\prime} \mathrm{W}\right.$, $39^{\circ} 26^{\prime} \mathrm{N}$ ). Kelp stand canopy was mapped using a portable geographical positioning (GPS) mapping system (SOKKIA, Axis 3) with satellite differential correction aboard a $12 \mathrm{ft}(3.7 \mathrm{~m})$ inflatable raft.

Data analysis. For the purpose of spatial analysis, outliers and positions with large estimated positional errors were removed. Any position recorded at a distance greater than $1000 \mathrm{~m}$ from the buoy array center was considered an outlier ( $0.5 \%$ of positions). Positional accuracy attenuates as a function of distance from the array center. The rate of attenuation depends on the exact placement of the buoys as well as the acoustic environment. Even with ideal placement and conditions, attenuation error is likely to exceed $\pm 50 \mathrm{~m}$ when detecting a tag $>1000 \mathrm{~m}$ from the array center (D. Webber, Vemco developer, pers. comm.).

During data collection, certain data files were noted to contain obviously erroneous calibrated buoy positions. The VRAP system was programmed to re-calibrate inter-buoy distances every hour, since changes in tidal height, prevailing winds and currents can cause the buoys to shift in their geographic position relative to their moorings. Inter-buoy distance is calibrated based on the time it takes for a generated acoustic signal to travel from one buoy to another. These signals can be blocked or distorted by background noise and interference at the water/air interface, resulting in calibration errors. Data received during periods of poor inter-buoy calibration were excluded from home range and core area calculations. We excluded any period for which a single, calibrated buoy position was $>10 \mathrm{~m}$ from the mean value $(11.3 \%$ of recording periods). These $1 \mathrm{~h}$ periods were interspersed throughout the study period and distributed evenly between day and night. Since the temporal component of the positions was not affected, this data was only removed for spatially referenced calculations.

For comparison, we used 2 methods to estimate home range. First we calculated the 'minimum convex polygon' (MCP) (Hayne 1949). Since the MCP is evaluated from the outermost points, home range area is highly correlated with the number of observations used, especially for small sample sizes (Worton 1987). As a conservative method to determine whether our sampling period was adequate for estimating home range area, we plotted estimated cumulative home range area over the period of observation following the method of Odum \& Kuenzler (1955).

We will refer to the second method for calculating home range size as the 'time density matrix' (TDM) method. This method is similar in most respects to that described in Parsons et al. (2003). The TDM method was used to estimate contours of utilization density where time is the density variable. Note that this differs from other methods such as Kernel Utilization Distributions (Worton 1989), which use independent positions as the density variable. The tracking area was divided into $5 \times 5 \mathrm{~m}$ grid cells, and the time that an individual fish was observed in each grid cell was calculated from the sum of vectors connecting consecutive positions. We assumed that individuals traveled in a straight line between consecutive positions at a constant and unique velocity determined by the distance divided by the time between positions. Vectors with a period between positions exceeding 30 min were excluded; in these cases we assumed the individual was sheltering and undetectable by the VRAP array. Detection rates were nearly continuous during the day, but nocturnal movement was sporadic and infrequent $(11.2 \%$ of all detections occurred at night). Also, all nighttime positions occurred within the perimeter of daytime positions. Therefore, only positions during twilight hours were included for the TDM estimation. The home range was then determined as the area made up of those $5 \mathrm{~m}$ cells which, when cumulatively summed in decreasing order of density, accounted for a $99 \%$ of the total time an individual was tracked (TDM99). For these calculations we used Matlab software (MathWorks, 1998 version).

Density-based estimates of 'space use' in animals often result in long-tailed distributions (Anderson 1982). The slope of the distributional curve can be nearly horizontal at the outer limit of the activity area (where the activity accounted for approaches 100\%). Therefore, occasional outlying movements or errors may have a disproportionately large effect on the estimate. A more accurate estimate can be attained using a smaller utilization percentage. We estimated home range from the $99 \%$ utilization area (TDM99)

Within the home range of each tagged individual, we identified core areas defined as the area within the home range in which an individual spent more time than if the total time were distributed uniformly throughout the home range (Samuel et al. 1985). We modified the Samuel et al. (1985) method by using total time per cell(s) rather than number of positions per cell as the density variable. We used a chi-square test on the observed and expected cell densities $(\mathrm{df}=$ cells -1 , 
$\mathrm{p}<0.001$ ) to test for significant difference between the observed distribution and the null hypothesis of a uniform distribution (Samuel \& Greene 1988). The size of the core area was estimated by summing those $5 \mathrm{~m}$ cells of the home range with values exceeding the hypothetical equal-use pattern. A discrete core area was considered an area made up of continuously adjacent core cells. The number of core areas was calculated by counting the discrete core areas separated by non-core spaces.

To estimate behavior during periods of non-detection, we plotted for each individual the first and last position between which a period > 30 min had lapsed. We assumed that these positions approximated shelter locations. However, a lapse of up to 200 s (VRAP detection cycle) could separate the instant when an individual entered or left a shelter and the next/previous acquired position, increasing variance. To increase the probability of accurate shelter estimates we removed all first/last pairs separated by a linear distance greater than $10 \mathrm{~m}$, then additionally removed, as outliers, the 2 farthest pairs from the mean $x$ and $y$ cluster center for each individual. This resulted in a total of 322 positions clustered by individual. We plotted density ellipses for each cluster and assigned 95\% confidence curves to shelter location estimates, assuming a bivariate normal distribution of the positions.

We compared nocturnal activity (number of positions recorded per night) with mean daily water temperature, nightly PFEL upwelling indices, wind velocity, maximum tidal range and lunar phase. We used Pearson's cross-correlation statistic to compare nocturnal activity with these physical variables, as well as to make comparisons between physical variables. Correlations between physical variables were over somewhat longer time periods (48 to $62 \mathrm{~d}$, depending on the variables) than those including nocturnal activity (21 d). We accounted for serial autocorrelation in the cross-correlation analysis, and adjusted the effective degrees of freedom accordingly (Botsford \& Paulsen 2000). Significance of the correlations was then determined using the standard method based on the distribution of cross correlations between 2 independent white noise series.

To determine whether tagged rockfish swam to pinnacles outside the kelp canopy less frequently during peak upwelling periods, we compared the number of positions acquired at these pinnacles (within a $20 \mathrm{~m}$ radius) when the PFEL index was $\geq 100 \mathrm{~m}^{3} \mathrm{~s}^{-1}$ versus when the PFEL index was $<100 \mathrm{~m}^{3} \mathrm{~s}^{-1}$. Counts were normalized by the duration of each period, and then summed to create a contingency table of the expected and observed ratio of counts for peak upwelling versus relaxation periods. A chi-square test $\left(1 \mathrm{df}_{;} \mathrm{p}<0.001\right)$ was used to test significance.

\section{RESULTS}

\section{Spatial distribution}

Tagged Sebastes mystinus moved within a habitat from 9 to $19 \mathrm{~m}$ depth from shore to seaward edge, with a thick stand of Nereocystis leutkeana forming a canopy out to the $14 \mathrm{~m}$ depth contour; $90 \%$ of all positions recorded were within the kelp canopy. Positions were generally concentrated away from the kelp stand interior and more along its outer edges. In all cases, home ranges extended across the seaward edge of the kelp stand (Fig. 2). The distribution of positions acquired as a function of distance from the outer kelp perimeter indicated that tagged individuals spent the greatest amount of time inside the kelp canopy between 10 and $20 \mathrm{~m}$ from the kelp-stand edge (Fig. 3). Note that the number of positions dropped more steeply with distance from the canopy edge outside the kelp, and more gradually inside. This result was consistent with observations of higher blue rockfish density just inside the kelp perimeter during SCUBA surveys $(>80 \mathrm{~h}$ ) and tagging efforts $(\mathrm{N}=675$ individuals tagged with Floy tags) conducted during the same period (M. O'Farrell \& S. Jorgensen pers. obs.). The boulder-covered bottom was punctuated with high relief rock formations, resulting in a series of isolated pinnacles extending from one-third to halfway up into the water column toward the surface. During SCUBA surveys and tagging, S. mystinus were primarily observed at these pinnacles, from which dense kelp stands grew. The distribution of telemetry positions was similarly highly clumped. After plotting the tracking data, we noted the coordinates for the center of each discrete cluster of positions. We then returned to survey these locations at the study site. In each case; the noted coordinate locations coincided with a large pinnacle (Fig. 4).

\section{Home range}

Tagged blue rockfish maintained a very small home range, rarely venturing beyond $100 \mathrm{~m}$ from the core area (Fig. 2). The mean estimated home range of tagged Sebastes mystinus using MCP 100 (i.e. based on 100\% of the positions) was $36716 \mathrm{~m}^{2} \pm 6202 \mathrm{SE}$. We plotted estimated cumulative area over the period of observation as a conservative method to determine whether our sampling period was adequate for estimating home range. The cumulative estimate of the home range area from the MCP 100 increased by less than 1\% daily after Day 18 (Fig. 5). The mean estimate of home range using the preferred TDM 99 method was $8783 \mathrm{~m}^{2} \pm 1137$ (Table 2). 

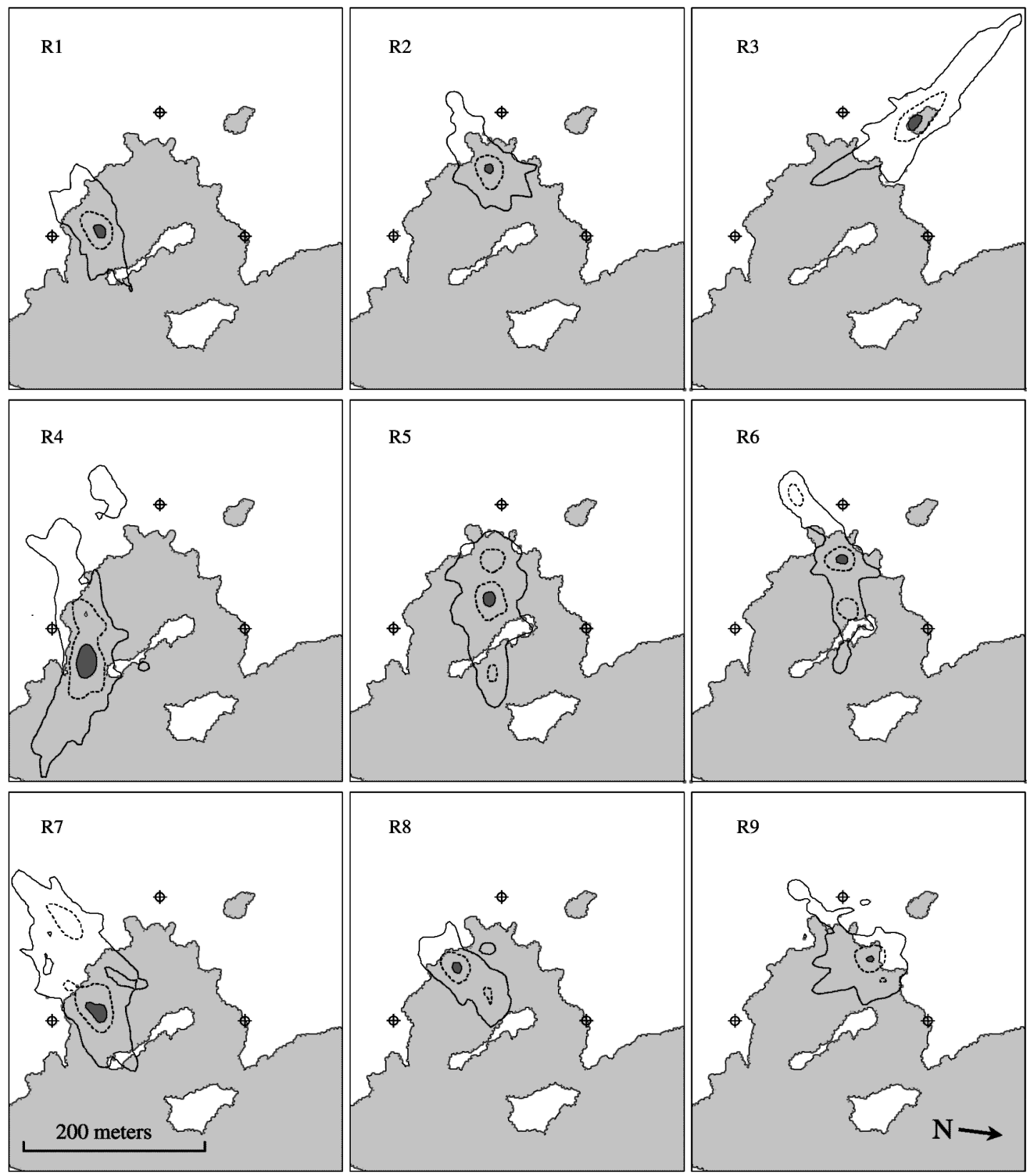

Fig. 2. Sebastes mystinus. Home ranges and core areas for 9 individuals (R1-R9; not calculated for R1O, as only $6 \mathrm{~d}$ of data were recorded for this individual). Outer polygons (black outline) demarcate home range estimated from $99 \%$ 'time density matrix' (TDM 99). Individuals maintained between 1 and 3 core areas (dashed outline), mostly along seaward edge of kelp canopy

(shaded area). Innermost polygon (dark grey) demarcates area containing $50 \%$ of activity. ( $\oplus$ ) Locations of VRAP buoys

It is important to note that nocturnal periods were omitted from the TDM estimations due to an inability to detect individuals sheltering in crevices. Had night periods been included, the density of the cell in which the shelter was located would have been greatly increased. Since estimated shelter locations for all tagged individuals occurred within the central part of the home range, the TDM 99 estimate would have necessarily been somewhat smaller in area.

\section{Core areas}

The number of cores used by individuals ranged between 1 and 3 (Fig. 2); 2 individuals utilized 3 cores, 3 individuals used 2 cores, and 4 maintained a single core (Table 2). The mean total core area was $1350 \mathrm{~m}^{2} \pm 286$ SE. All core areas coincided with submarine pinnacles. There was no significant difference in home range area (Student's $t$-test, $\mathrm{p}=0.906,7 \mathrm{df}$ ) or total core area $(t$-test, 


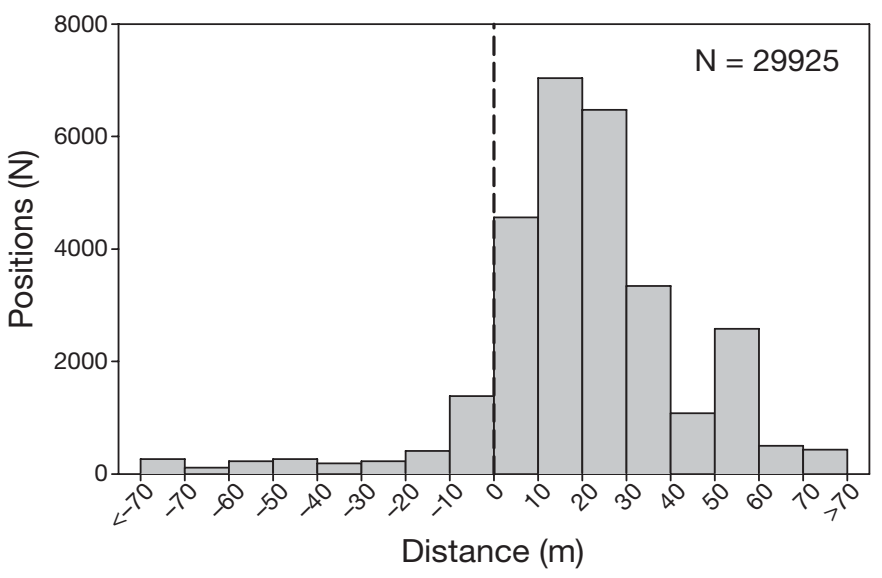

Fig. 3. Sebastes mystinus. Distribution of positions acquired ( $\mathrm{N}=$ total no.) relative to distance from kelp canopy perimeter (vertical dashed line). Negative values indicate positions outside, positive values positions inside kelp canopy

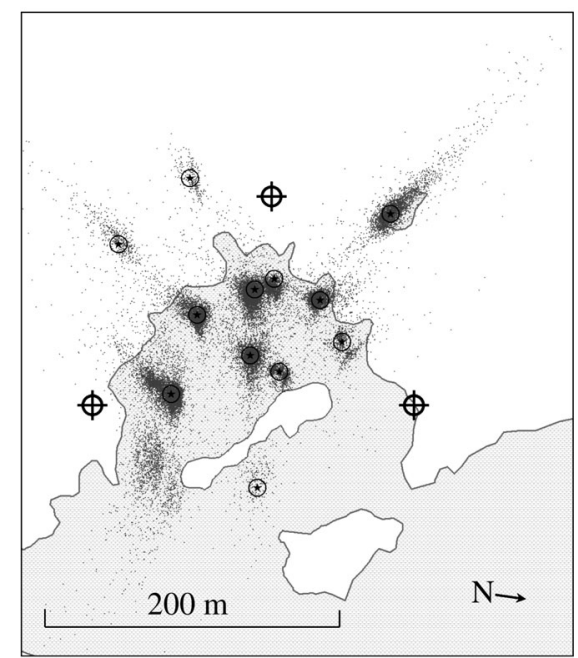

Fig. 4. Sebastes mystinus. Mapped submarine pinnacles (circled stars) relative to clumped distribution (gray dots) of all recorded positions. $(\oplus)$ VRAP buoys $\mathrm{p}=0.696,7 \mathrm{df}$ ) among individuals with a single core and those with multiple cores. For individuals using multiple core areas, not all cores were used each day. Consistent patterns of core usage persisted from 2 to $6 \mathrm{~d}$, during which an individual used all or just a subset of cores; this was followed by a shift to an alternate pattern, which again persisted, and so forth. This pattern is illustrated for Individuals R6 and R7 which moved between 3 and 2 core areas, respectively (Fig. 6). The timing of core usage is shown over the study period in Fig. 6A, and as a function of time of day in Fig. 6C. Note that nocturnal activity was always confined to a single core.

Table 2. Home range and core area estimates for tagged Sebastes mystinus using the $100 \%$ minimum convex polygon (MCP 100), and 99\% time density matrix (TDM 99) methods

\begin{tabular}{|c|c|c|c|c|}
\hline ID & $\begin{array}{l}\mathrm{MCP} 100 \\
\left(\mathrm{~m}^{2}\right)\end{array}$ & $\begin{array}{c}\text { TDM } 99 \\
\left(\mathrm{~m}^{2}\right)\end{array}$ & $\begin{array}{rc}\mathrm{Cc} \\
\text { No. used }\end{array}$ & d Area $\left(\mathrm{m}^{2}\right)$ \\
\hline R1 & 31882 & 6500 & 1 & 825 \\
\hline R2 & 15109 & 5500 & 1 & 675 \\
\hline R3 & 59294 & 9750 & 1 & 1275 \\
\hline R4 & 58846 & 14050 & 1 & 3175 \\
\hline R5 & 32857 & 10500 & 3 & 1500 \\
\hline R6 & 21432 & 6075 & 3 & 1000 \\
\hline R7 & 63229 & 13850 & 2 & 2275 \\
\hline R8 & 24100 & 5625 & 2 & 775 \\
\hline R9 & 23698 & 7200 & 2 & 650 \\
\hline $\mathrm{R} 10^{\mathrm{a}}$ & 16477 & 5350 & 1 & 800 \\
\hline $\begin{array}{l}\text { Mean } \pm \text { SE } \\
(\mathrm{R} 1-\mathrm{R} 9)\end{array}$ & $36716 \pm 6202$ & $8783 \pm 1137$ & & $1350 \pm 286$ \\
\hline \multicolumn{5}{|c|}{$\begin{array}{l}\text { a Only } 6 \text { d data recorded for } \mathrm{R} 10 \text {; therefore mean } \pm \text { SE are } \\
\text { based on } 9 \text { individuals }\end{array}$} \\
\hline
\end{tabular}

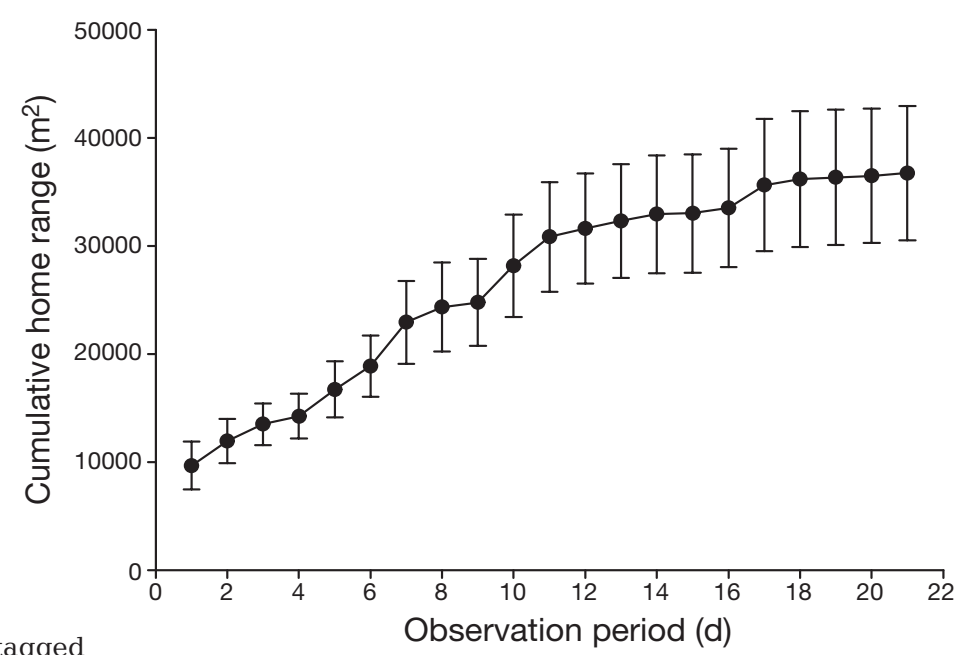

Fig. 5. Sebastes mystinus. Cumulative estimates (mean $\pm \mathrm{SE}$; $\mathrm{N}=9$ ) of home range using the minimum convex polygon method. After 18 d observation, successive estimates increased by $<1 \%$

There was a high degree of overlap of core areas, suggesting no territoriality during diurnal activities. However, unique responses occurred for even highly overlapping individuals (Fig. 7). In these cases ( $\mathrm{N}=3$ individuals in both Fig. 7A and B), large sections of the overlapping core's edges coincided. However, individuals differed in the number or location of additional core areas. While core areas overlapped considerably, we found that the estimated locations of nocturnal shelters, based on $95 \%$ confidence limits, were separate for each individual. All estimated shelter locations were centered within the core area of the respective individual. 
A

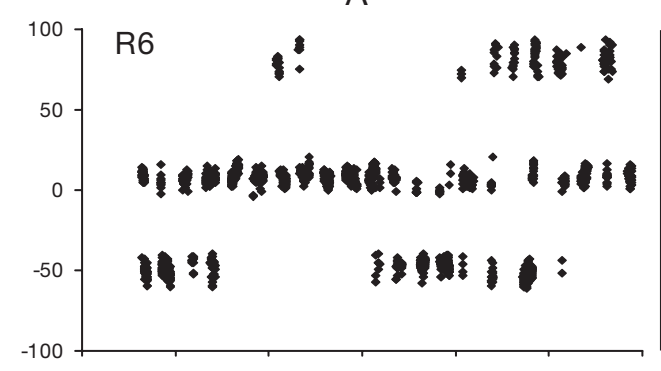

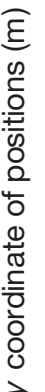
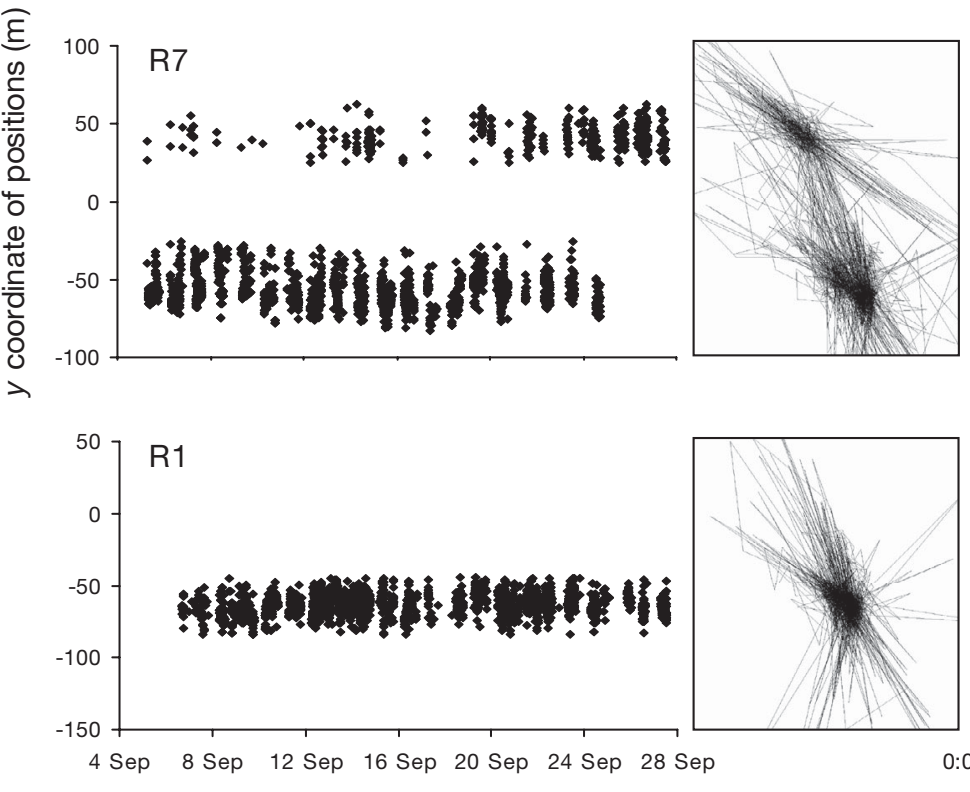

Date

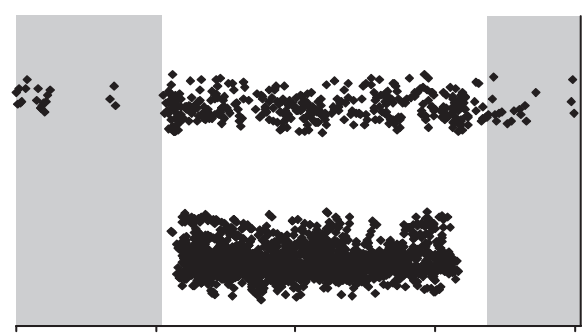

B
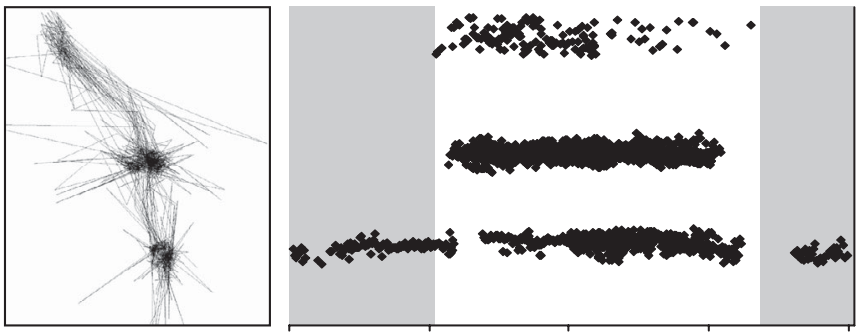

C

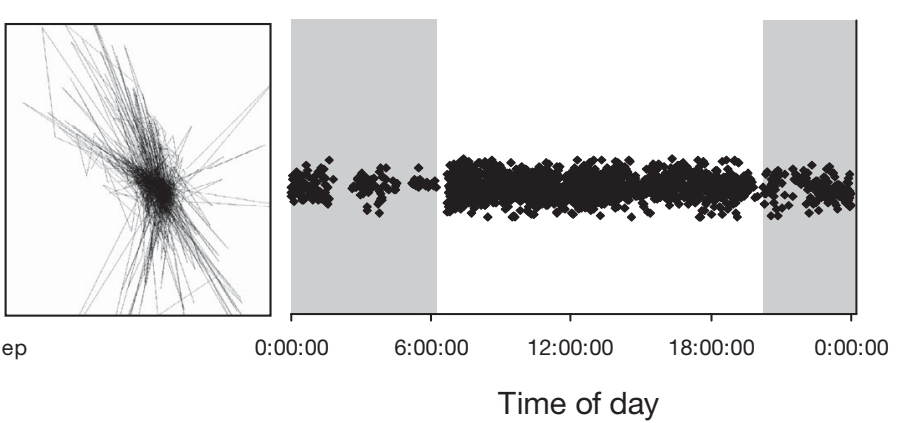

Fig. 6. Sebastes mystinus. Comparison of movement within and between core areas among individuals. Rockfish No. 6 (R6) used 3 cores, R7 used 2, and R1 a single core. (A) Distribution of within-core positions (on y-coordinate relative to Cartesian grid origin) over $3 \mathrm{wk}_{i}$ (B) vectors connecting all consecutive positions; (C) distribution of within-core positions as a function of time of day

\section{Movement}

Tagged Sebastes mystinus remained near pinnacles along the seaward edge of the kelp bed, making punctuated and brief radial excursions away from these centers or moving directly from one pinnacle to the next along defined corridors (Fig. 6B). All individuals exhibited high site fidelity at pinnacles. We found that the mean displacement between consecutive positions originating and ending inside core areas $(6.19 \mathrm{~m} \pm 0.04)$ was nearly 6 -fold smaller than for steps originating or ending outside $(36.04 \mathrm{~m}$ \pm 0.40 ) (Table 3).
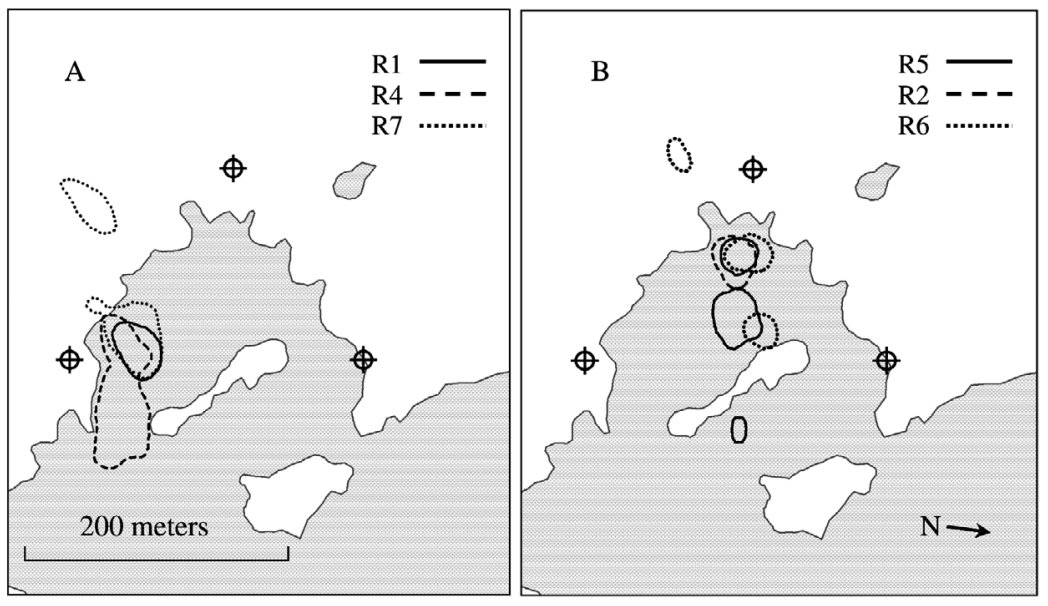

Fig. 7. Sebastes mystinus. Overlapping core areas at 2 centers (pinnacles) for (A) Fish R1, R4 and R7, and (B) Fish R2, R5, and R6. Fish descriptions in Table 2, lines and symbols as in Fig. 2 
Table 3. Length and duration (mean \pm SE) of steps between sequential positions. Steps inside cores include only those with both start and end positions inside core area. Outside core steps are those with 1 or both positions outside core area. $\mathrm{N}=$ no. of observations for all tagged fish

\begin{tabular}{|lrrrr|}
\hline Position & $\begin{array}{c}\text { Step length } \\
(\mathrm{m})\end{array}$ & $\begin{array}{c}\text { Median } \\
(\mathrm{m})\end{array}$ & $\begin{array}{c}\text { Step duration } \\
(\mathrm{s})\end{array}$ & $\mathrm{N}$ \\
\hline Overall & $13.61 \pm 0.13$ & 5.91 & $197.0 \pm 0.1$ & 28120 \\
Inside cores & $6.19 \pm 0.04$ & 4.12 & $196.9 \pm 0.1$ & 21210 \\
Outside cores & $36.04 \pm 0.40$ & 26.42 & $197.3 \pm 0.1$ & 6910 \\
\hline
\end{tabular}

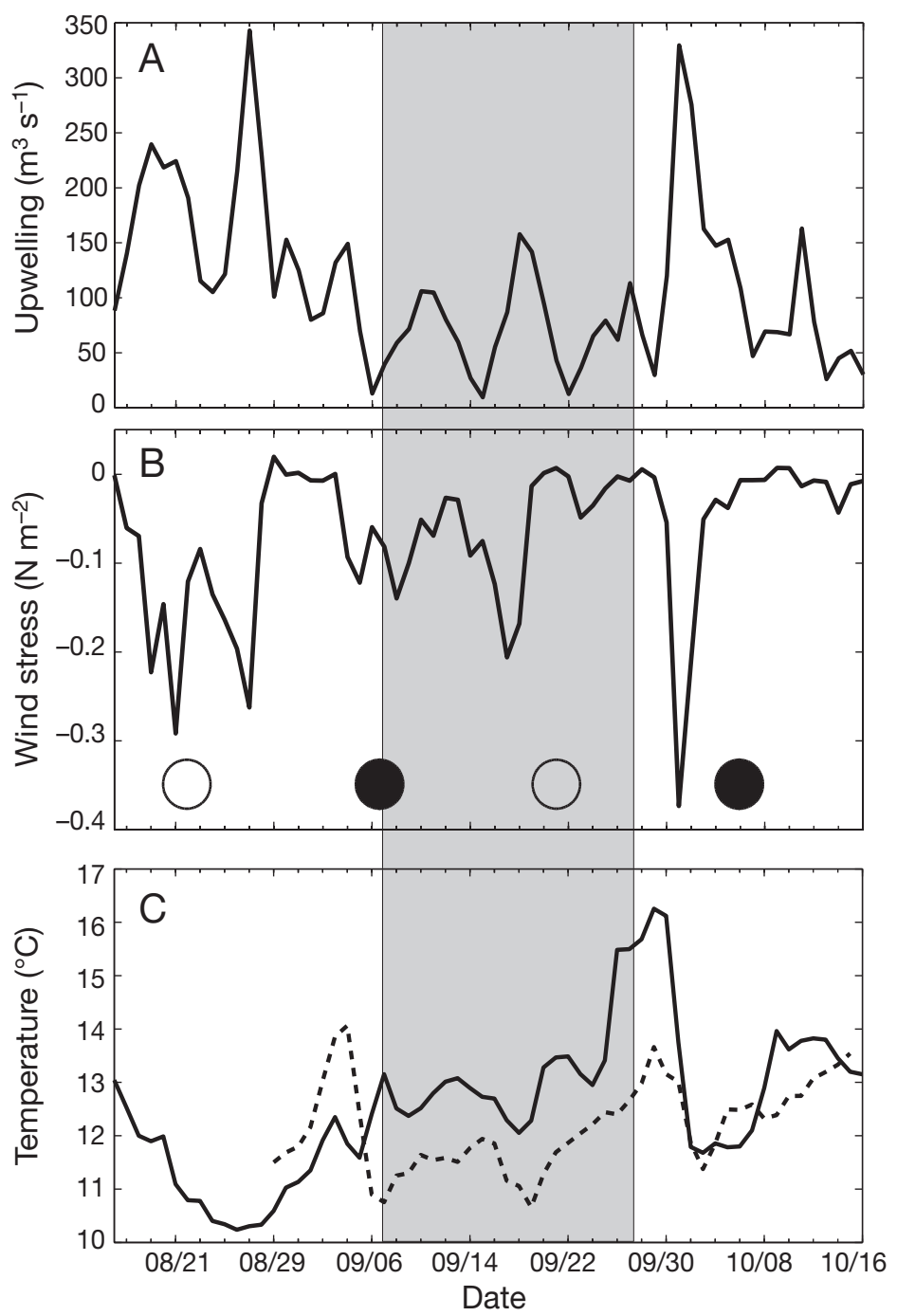

Fig. 8. Physical oceanographic variables during study season, showing (A) upwelling index; (B) principal axis wind stress, and (C) temperature at Offshore Buoy 46013 (continuous line) and in situ (dashed line). Gray area: study period, full moon $(\mathrm{O})$, new moon $(\bullet)$. Negative windstress values indicate equatorward (upwelling favorable) winds. Dates (2002) presented as mo/d

\section{Response to environmental conditions}

During the time period of the study, winds were generally weak, but punctuated with events of moderate, upwelling-favorable conditions (Fig. 8), typical of this area during late summer. There were 2 upwelling periods during the study - an extended, weak event between September 4 and 9 and another, more pronounced event from September 16 to 19 (Fig. 8B). This pattern is reflected in the regional upwelling index (Fig. 8A). Both study-site temperature and NDBC surface temperature dropped during these events (Fig. 8C), although the response was somewhat different, as might be expected given the sites' different locations and depths. The NDBC principal-axis wind stress and PFEL upwelling index were significantly negatively correlated, with time lags of 0 and $1 \mathrm{~d}$ (correlation of -0.62 for a lag of $0 \mathrm{~d}, \mathrm{~N}=62 \mathrm{~d}$, adjusted $\mathrm{df}=33, \mathrm{p}<0.001$ ). Principal-axis wind stress was significantly correlated with NDBC and Fort Ross water temperature, with lags of 1 to 5 and 1 to $3 \mathrm{~d}$, respectively (wind precedes temperature; at Fort Ross, maximum correlation of 0.59 with a lag of $2 \mathrm{~d}, \mathrm{~N}=48$, adjusted $\mathrm{df}=23, \mathrm{p}=0.003$ ). A lag in the order of $2 \mathrm{~d}$, whereby wind precedes temperature response, is characteristic of this coastal-upwelling system (Wing et al. 1995b). Lunar phase and the period of nocturnal lunar presence during the study increased from the new moon on September 6 to a peak level of illumination during the full moon on September 21.

Detection rates for tagged individuals dropped steeply at dusk and resumed at dawn (Fig. 9). The crepuscular transition between near continuous daytime detection to low nocturnal detection rates coincided precisely with nautical twilight times at the mid point of the study period (06:00 and 20:10 h, respectively), suggesting that circadian activity patterns for Sebastes mystinus are tightly linked to ambient light levels.

Although activity level, measured as the number of positions acquired over time, was nearly an order of magnitude lower after nightfall (Fig. 9), some level of nocturnal activity was detected for all individuals. In all cases, nocturnal activity was confined to a single core area (Fig. 6C). Nocturnal activity ranged from 3 to 485 positions per night and was negatively correlated with the PFEL upwelling index (correlation of $-0.62, \mathrm{~N}=21$, adjusted $\mathrm{df}=13, \mathrm{p}=0.023$ ) with a lag time of $1 \mathrm{~d}$ (Fig. 10). Fort Ross water temperature was also correlated with the number of night positions, with a lag of $1 \mathrm{~d}$, but not significantly (correlation of $0.58, \mathrm{~N}=21$, adjusted $\mathrm{df}=11, \mathrm{p}=0.068$ ). Diurnal detection rates were relatively constant and did not vary significantly with upwelling index, wind or water temperature. Correlations of nocturnal activity levels with tidal range, lunar phase and the period of nocturnal lunar presence were 


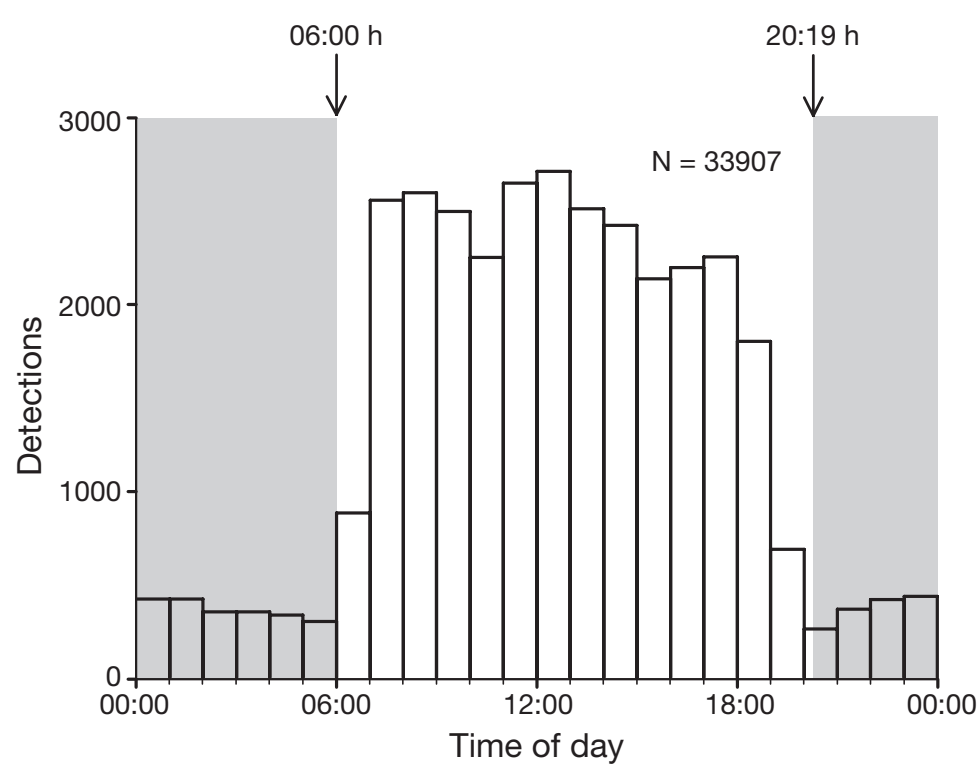

Fig. 9. Sebastes mystinus. Distribution of detections $(\mathrm{N}=$ total no.) as a function of time of day for 10 tagged individuals over 3 wk study period. Nautical twilight at halfway point of study (September 17, 2002) is indicated by arrows between gray (night) and open (day) areas

not significant $(\mathrm{p}>0.5)$. Also, neither lunar phase nor tidal range were correlated with Fort Ross temperature.

Periodically, 5 tagged individuals visited 2 pinnacles outside the kelp canopy (Fig. 4). The total number of positions acquired at these pinnacles was significantly lower during the peak upwelling periods during the study (Chi-square $=95.400 ; 1$ df, p < 0.001) (Fig. 10)

\section{DISCUSSION}

Blue rockfish have remarkably small home ranges that appear to be influenced by the interaction of oceanographic variability, structural species (kelp) and physical habitat. Within $18 \mathrm{~d}$, cumulative measurements of the home range area approached an asymptote. Using the TDM method, we derived statistics to describe the relative usage of space within the home range. Approximately $83 \%$ of an individual's activity occurred in core areas that accounted for only $~ 14 \%$ of the total home range area. An analysis of the detailed data provides new insights about blue rockfish movement in terms of their spatial distribution and usage of core areas within the home range.

\section{Habitat utilization}

Spatial movement patterns of tagged blue rockfish were closely associated with particular habitat fea- tures; $90 \%$ of positions were within the borders of the kelp canopy, and these were largely concentrated along the seaward edge (Fig. 3). The utilization of the seaward edge of kelp beds by blue rockfish (Hallacher \& Roberts 1985, Hobson et al. 1996) and other planktivores along the eastern Pacific shores (e.g. Bray 1981) has been linked to the observed strong gradient from high to low planktonic prey density between the seaward and shoreward edges, respectively, of coastal fringing kelp beds (Gaines \& Roughgarden 1987) and between in-current and out-current ends of discrete kelp stands (Bray 1981). Gaines \& Roughgarden (1987) showed that concentrations of small plankton in kelp beds in central California were an order of magnitude higher offshore versus inshore. However, these differences existed only when planktivorous juvenile rockfish were present. Moreover, they found a parallel gradient in the number of planktonic prey items found in the stomachs of juvenile Sebastes mystinus from inshore to offshore locations in the kelp beds, suggesting that rockfish were maintaining low plankton densities inside the kelp beds. Given the very high densities of adult rockfish at our study site, it is possible that a similar gradient exists for the larger plankton food items of adults, making the offshore edge favorable for prey encounter rates.

Tagged rockfish displayed high affinity with submarine pinnacles (Fig. 4), which are likely to be important either for physical shelter, spatial orientation, or both. There are 2 hypotheses, not necessarily mutually exclusive, that may explain the close association of Sebastes mystinus with pinnacles: (1) Pinnacles allow adults to feed high in the water column, appropriate to the abundance of their preferred prey items (Hobson \& Chess 1988), while providing immediate structural refuge from predation; (2) pinnacles serve as a spatial reference, facilitating optimal response to feeding opportunities and the presence of predators.

Support for the second hypothesis stems partially from the reasoning that without the need for spatial familiarity, fidelity to any specific pinnacle(s) would not be important, and we may expect frequent drifting or relocation of activity centers. However, we observed strong pinnacle fidelity and repeated movements between the same pinnacles. Miller \& Geibel (1973) also found strong site fidelity over longer (yearly) time scales. They reported over 350 Sebastes mystinus recaptures at a precise tagging location over a period of $3 \mathrm{yr}$.

The use of pinnacles for spatial reference also seems likely since tagged rockfish displayed keen spatial familiarity, swimming directly and rapidly between pinnacles up to $100 \mathrm{~m}$ apart (Fig. 6B). Also, individuals who used multiple pinnacles did not move among only 


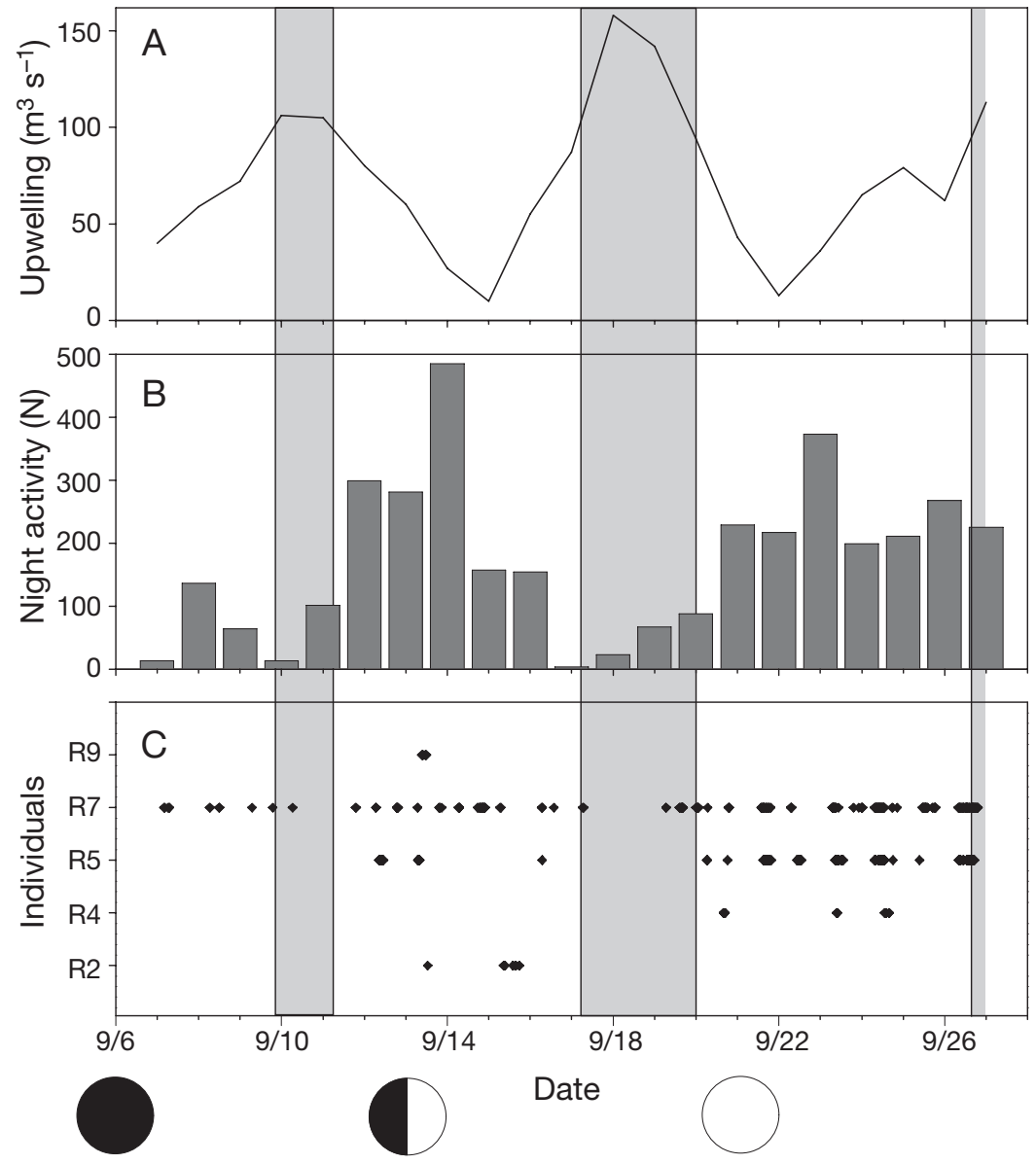

Fig. 10. Sebastes mystinus. Activity during peak upwelling (light gray) periods. (A) Upwelling index correlated with (B) nocturnal activity level, measured as number of detections per night. (C) presence ( $)$ of 5 ind. (R2, 4, 6, 7 and 9) at 2 pinnacles beyond kelp canopy. Dates (2002) presented as mo/d. Moon phase is indicated below $x$-axis (new moon $=\operatorname{Sep} 6$; first quarter $=$ Sep 13; full moon $=$ Sep 21; last quarter $=$ Sep 29)

those that were closest; some tagged individuals repeatedly swam past nearby pinnacles to reach a particular pinnacle further away. Spatial familiarity might include well-established routes between pinnacles, or the route to a crevice shelter within close proximity to a central pinnacle, along which an individual could reflexively retreat to its shelter.

In this study, blue rockfish were closely associated with the kelp canopy. Although Sebastes mystinus also occur at deeper reefs away from kelp forests (Miller \& Geibel 1973, Love et al. 2002), we observed relatively few individuals in adjacent deeper water during diver surveys $(>80 \mathrm{~h})$ and mark/recapture efforts ( $\mathrm{N}=675$ blue rockfish) (M. O'Farrell \& S. Jorgensen pers. obs.) compared to large and dense aggregations under the kelp canopy. This suggests that, when kelp is abundant, blue rockfish may prefer it to adjacent areas without kelp.

\section{Spatial movement}

Blue rockfish movements were restricted to a surprisingly small area and their movements were highly structured spatially. Vectors connecting consecutive positions were much smaller within the core areas than outside or between cores (Fig. 6B). Each core area was centered at a discrete pinnacle, and many of the tagged individuals' cores overlapped. Individuals only left these centers for brief radial movements or rapid and direct moves to another pinnacle. Similar patterns of radial movement from a central position have been observed among refuging birds, such as starlings (Hamilton et al. 1966), and among hammerhead sharks (Klimley \& Nelson 1984). In such central-core refuge systems, intraspecific competition for resources is assumed to decline with increasing distance from the center (Hamilton \& Watt 1970).

A possible explanation for the observed high levels of activity of blue rockfish near physical structures is that such structures perform an anti-predation function. The distribution of resources and the risk of predation to a forager are often the major interacting variables that regulate consumer movement (Covich 1976, Ogden \& Quinn 1984, Hixon \& Carr 1999). If predation pressure is high, strong selection for predator avoidance behavior can be expected (Dingle \& Holyoak 2001). Blue rockfish predators include seals, sealions, other rockfish (Sebastes spp.) and lingcod (Ophiodon elongatus). While performing SCUBA surveys during the study period, we commonly observed all these predators. The observed movement away from core areas of protective cover and high congener density might increase the probability of encountering planktonic prey, yet this decision could be countered by the extrinsic constraint of increased predation probability.

Tagged rockfish frequented 1 to 3 pinnacles, which comprised their core area(s). In 2 separate instances there was high overlap of core areas among 3 tagged individuals, each group occurring around a single central pinnacle (Fig. 7). In both cases, overall individual outcomes were unique in terms of the total number or location of additional core areas, despite similarities in the spatial extent and shape of the shared areas. Also, the estimated locations of night 
shelters in these cases, and indeed in all 10 cases, were separate from each other.

A strategy of multiple refugia is employed by many mammals in terrestrial systems (e.g. burrowing herbivores, Covich 1976). Theoretically, maintaining multiple centers of refuge can allow a forager to exploit a larger area without exceeding a maximum distance from the nearest shelter. We did not find a difference in the home range or core area size among morphologically similar individuals maintaining 1 versus multiple cores. Rather, individual cores were larger among single core users than among individuals using multiple cores ( $t$-test; $N=16, p=0.021)$. Interestingly, the size of individual cores decreased linearly with increasing number of cores used $\left(\mathrm{N}=16, \mathrm{R}^{2}=0.293, \mathrm{p}<0.001\right)$. As a result, the total area used by individual rockfish remained constant regardless of the number of cores maintained.

\section{Temporal activity}

The close correspondence between the observed circadian activity cycle and ambient light levels indicated by nautical twilight periods (Fig. 9) might be explained by absolute light sensitivity levels in Sebastes mystinus. The minimal light flux necessary to evoke a consistently observable electrical response from retinal photoreceptors in S. mystinus was below moonlight (full moon at $10 \mathrm{~m}$ depth) irradiance levels (C. Reilly unpubl. data). In contrast, the nocturnal congener $S$. serranoides displayed observable responses to the same stimuli. The apparent inability of blue rockfish to see at night might explain why they appear to shelter after dark, and also why the limited movement that did take place did not correlate with increasing lunar phase.

Nocturnal sheltering of blue rockfish is consistent with increased nocturnal activity of their potential predators, such as lingcod (Mathews 1990, 1992). In addition to poor night vision, other vulnerabilities include a small mouth (Hallacher \& Roberts 1985) and virtually no defensive head spines (Love et al. 2002). Tagged individuals seldom left their shelter after dark (only $11.2 \%$ of detections were at night). Similarly, only $10.2 \%$ of all positions were recorded outside the kelp canopy, even though the home ranges of 5 tagged individuals included pinnacles beyond the canopy perimeter (Figs. $2 \& 3$ ).

Movements at night and to pinnacles outside the kelp canopy occurred significantly less frequently during active upwelling during the study period. We hypothesize that tagged rockfish ventured out at night or beyond the kelp's structural refuge only during periods when preferred food items were likely to be more abundant, thereby offsetting any increased probability of preda- tion. Coastal upwelling moves surface waters off the shelf (Strub et al. 1987) that are replaced with deeper water that is low in plankton, potentially reducing food availability for blue rockfish (Hobson \& Chess 1988). During relaxation in wind strength, this pattern reverses and nearshore plankton levels have been shown to increase (Wing et al. 1995a). This explanation of the observed correlation between movement patterns and upwelling is consistent and plausible, but must be viewed with some skepticism. The short temporal extent of this study makes a concrete determination of the causal mechanisms difficult, and no measurement has been made of the factors that directly impact fish activity, such as food availability. Furthermore, the time period of this study does not correspond to the peak in upwelling conditions in the area (late spring, early summer), and we did not sample the full range of upwelling or water column conditions. Despite these limitations, the patterns observed during this study are intriguing and merit further investigation.

\section{CONCLUSION}

In this study, we examined the movement patterns of 10 blue rockfish over a time period of $24 \mathrm{~d}$. Detailed analyses of short-term movement patterns provided important insights; however, longer studies are needed to ascertain seasonal variation in the observed movement patterns. The spatial extent of blue rockfish movement during the study was very limited, typically $<100 \mathrm{~m}$ from a central core. Core areas were associated with the presence of rock pinnacles, particularly those pinnacles within a kelp canopy. Nocturnal activity and movement outside the kelp canopy was rare and significantly negatively correlated with upwelling strength. While we provide potential mechanisms that could explain the observed spatial and temporal movement patterns, testing of these alternative mechanisms remains a fertile area for future research.

Limited home range and core areas in marine fishes may have important consequences for marine reserve design. Detailed home range and core area information is vital for determination of optimal size and spacing of marine reserve networks. If indeed the home range sizes found in this study are representative over longer time periods, then it is likely that spillover of adults from edge effects will be quite limited in reserves larger than several kilometers.

Acknowledgements. This research was conducted in compliance with Univesity of California, Davis animal research protocol No. 102132, and D.F.G. permit No. 001349. We gratefully acknowledge our assistants J. Barlow and G. Clinton, whose vigorous support was essential to the project's success. 
We also acknowledge the following funding sources: JMIE, Sea Grant, and the Switzer foundation. This work was supported in part by a Graduate Assistantship from the Bodega Marine Laboratory, University of California at Davis. We thank A. Bolden, D. Kramer and E. Laca for comments and D. Parsons for assistance with the home range calculation code. We also thank W. Walton, S. Barlow and the entire Fort Ross staff for their support. The manuscript was greatly improved through review by 3 anonymous referees. This manuscript is contribution No. 2362 from the Bodega Marine Laboratory, University of California at Davis.

\section{LITERATURE CITED}

Anderson DJ (1982) The home range-a new nonparametricestimation technique. Ecology 63:103-112

Botsford LW, Paulsen CM (2000) Assessing covariability among populations in the presence of intraseries correlation: Columbia River spring-summer chinook salmon (Oncorhynchus tshawytscha) stocks. Can J Fish Aquat Sci 57:616-627

Bray RN (1981) Influence of water currents and zooplankton densities on daily foraging movements of blacksmith, Chromis punctipinnis, a planktivorous reef fish. US Natl Mar Fish Serv Fish Bull 78:829-841

Covich AP (1976) Analyzing shapes of foraging areas: some ecological and economical theories. Annu Rev Ecol Syst 7: 235-257

Dingle H, Holyoak M (2001) The evolutionary ecology of movement. In: Fox CW, Roff DA, Fairbairn DJ (eds) Evolutionary ecology. Oxford University Press, New York, p 247-264

Ellner SP, Fussmann G (2003) Effects of successional dynamics on metapopulation persistence. Ecology 84:882-889

Eristhee N, Oxenford HA (2001) Home range size and use of space by Bermuda chub Kyphosus sectatrix (L.) in two marine reserves in the Soufriere Marine Management Area, St Lucia, West Indies. J Fish Biol 59:129-151

Gaines SD, Roughgarden J (1987) Fish in offshore kelp forests affect recruitment to intertidal barnacle populations. Science 235:479-481

Hallacher LE, Roberts DA (1985) Differential utilization of space and food by the inshore rockfishes (Scorpaenidae: Sebastes) of Carmel Bay California USA. Environ Biol Fish 12:91-110

Hamilton JW, Watt KE (1970) Refuging. Annu Rev Ecol Syst 1: 263-287

Hamilton JW, Gilbert WM, Heppner FH, Planck RJ (1966) Starling roost dispersal and a hypothetical mechanism regulating rhythmical animal movement to and from dispersal centers. Ecology 48:825-833

Hanski I (1998) Metapopulation dynamics. Nature 396:41-49

Hayne DW (1949) Calculation of home range. J Mammal 30: $1-18$

Hill MF, Hastings A, Botsford LW (2002) The effects of small dispersal rates on extinction times in structured metapopulation models. Am Nat 160:389-402

Hixon MA, Carr MH (1997) Synergistic predation, density dependence, and population regulation in marine fish. Science 277:946-949

Hobson ES, Chess JR (1988) Trophic relations of the blue rockfish Sebastes mystinus in a coastal upwelling system off northern California USA. Fish Bull 86:715-744

Hobson ES, Chess JR, Howard DF (1996) Zooplankters consumed by blue rockfish during brief access to a current off California's Sonoma coast. Calif Fish Game 82:87-92
Holland KN, Lowe CG, Wetherbee BM (1996) Movements and dispersal patterns of blue trevally (Caranx melampygus) in a fisheries conservation zone. Fish Res 25:279-292

Holland KN, Wetherbee BM, Peterson JD, Lowe CG (1993) Movements and distribution of hammerhead shark pups on their natal grounds. Copeia 1993:495-502

Kenward RE, Clarke RT, Hodder KH, Walls SS (2001) Density and linkage estimators of home range: nearest-neighbor clustering defines multinuclear cores. Ecology 82: 1905-1920

King R, Lawson R (1995) Color-pattern variation in Lake Erie water snakes: the role of gene flow. Evolution 49:885-896

Klimley AP, Nelson DR (1984) Diel movement patterns of the scalloped hammerhead shark (Sphyrna lewini) in relation to El Bajo Espiritu Santo: a refuging central-position social system. Behav Ecol Sociobiol 15:45-54

Klimley AP, Le Boeuf BJ, Cantara KM, Richert JE, Davis SF, Van Sommeran S (2001) Radio acoustic positioning as a tool for studying site-specific behavior of the white shark and other large marine species. Mar Biol 138:429-446

Kramer DL, Chapman MR (1999) Implications of fish home range size and relocation for marine reserve function. Environ Biol Fish 55:65-79

Large WG, Pond S (1981) Open ocean momentum flux measurements in moderate to strong winds. J Phys Oceanogr 11:324-36

Love MS, Yoklavich M, Thorsteinson L (2002) The rockfishes of the Northeast Pacific. University of California Press, Berkeley, CA

Lowe CG, Topping DT, Cartamil DP, Papastamatiou YP (2003) Movement patterns, home range, and habitat utilization of adult kelp bass Paralabrax clathratus in a temperate notake marine reserve. Mar Ecol Prog Ser 256:205-216

Matthews KR (1990) An experimental study of the habitat preferences and movement patterns of copper, quillback, and brown rockfishes (Sebastes spp.). Environ Biol Fish 29:161-178

Matthews KR (1992) A telemetric study of the home range and homing routes of lingcod Ophiodon elongatus on shallow rocky reefs off Vancouver Island, British Columbia. Fish Bull (Wash DC) 90:784-790

Meyer CG, Holland KN, Wetherbee BM, Lowe CG (2000) Movement patterns, habitat utilization, home range size and site fidelity of whitesaddle goatfish, Parupeneus porphyreus, in a marine reserve. Environ Biol Fish 59: 235-242

Miller DJ, Geibel JJ (1973) Summary of blue rockfish and lingcod life histories, a reef ecology study; and giant kelp, Macrocystis pyrifera, experiments in Monterey Bay, California. Fish Bull Calif 158:1-137

Odum EP, Kuenzler EJ (1955) Measurement of territory and home range size in birds. Auk 72:128-137

Ogden JC, Quinn TP (1984) Migration in coral fishes: ecological significance and orientation mechanisms. In: McCleave J, Arnold G, Dodson J, Neill W (eds) Mechanisms of migration in fishes. Plenum Press, New York, p 293-308

Parsons DM, Babcock RC, Hankin RKS, Willis TJ, Aitken JP, O'Dor RK, Jackson GD (2003) Snapper Pagrus auratus (Sparidae) home range dynamics: acoustic tagging studies in a marine reserve. Mar Ecol Prog Ser 262: 253-265

Sale PF, Cowen RK, Danilowicz BS, Jones GP and 7 others (2005) Critical science gaps impede use of no-take fishery reserves. Trends Ecol Evol 20:74-80

Samuel MD, Green RE (1988) A revised test procedure for identifying core areas within the home range. J Anim Ecol $57: 1067-1068$ 
Samuel MD, Pierce DJ, Garton EO (1985) Identifying Areas of Concentrated Use within the Home Range. J Anim Ecol 54:711-719

Send U, Beardsley RC, Winant CD (1987) Relaxation from upwelling in the coastal ocean dynamics experiment. J Geophys Res C 92:1683-1698

Strub PT, Allen JS, Huyer A, Smith RL, Beardsley RC (1987) Seasonal cycles of currents, temperatures, winds, and sea-level over the Northeast Pacific Continental-Shelf$35^{\circ} \mathrm{N}$ to $48^{\circ} \mathrm{N}$. J Geophys Res C 92:1507-1526

Topping DT, Lowe CG, Caselle JE (2005) Home range and habitat utilization of adult California sheephead, Semicossyphus pulcher (Labridae), in a temperate no-take marine reserve. Mar Biol 147:301-311

Editorial responsibility: Howard Browman (Associate Editorin-Chief), Storebø, Norway
Wing SR, Botsford LW, Largier JL, Morgan LE (1995a) Spatial structure of relaxation events and crab settlement in the northern California upwelling system. Mar Ecol Prog Ser 128:199-211

Wing SR, Largier JL, Botsford LW, Quinn JF (1995b) Settlement and transport of benthic invertebrates in an intermittent upwelling region. Limnol Oceanogr 40:316-329

Woodroffe R, Ginsberg JR (1998) Edge effects and the extinction of populations inside protected areas. Science 280: $2126-2128$

Worton BJ (1987) A review of models of home range for animal movement. Ecol Model 38:277-298

Worton BJ (1989) Kernel methods for estimating the utilization distribution in home range studies. Ecology 70:164-168

Submitted: July 1, 2005; Accepted: January 9, 2006 Proofs received from author(s): November 15, 2006 